\title{
Milk production in Finnsheep and Romanov breeds ${ }^{1}$
}

\author{
W.J. BOYLAN and H. SAKUL \\ Department of Animal Science, University of Minnesota \\ St. Paul, MN 55108, U.S.A.
}

\begin{abstract}
The Finn, Romanov and several U.S. sheep breeds were machine milked to obtain information on several measures of milk production and milk composition. Data were obtained over a two year to four year period utilizing 146 purebred ewe records and 165 crossbred ewe records. The level of milk production for a 130 day lactation period for the breeds evaluated was generally low compared to traditional European dairy breeds. The least-squares overall mean for milk yield was 68.8 liters. The Suffolk (80.5 liters) and the Rambouillet (75.3 liters) were superior. The Targhee, Dorset and Lincoln breeds followed in order for milk yield. The Finn (64.0 liters) and Romanov (39.1 liters) were lowest. Finn sired crossbred ewes had the highest level of milk production (84.4 liters) in a four breed diallel mating design of Finn, Dorset, Lincoln and Rambouillet breeds. A value of $15.4 \%$ was found for heterosis in milk production.
\end{abstract}

Index words: sheep, breeds, milk, dairy sheep

\section{Introduction}

Sheep dairying is a major enterprise in many European and Middle Eastern countries. It is virtually nonexistent in the U.S. even though demand for cheese made from sheep milk is high. The U.S. annually imports more than 10 thousand metric tons of sheep milk cheese (6). There is a growing interest in

\footnotetext{
Paper No. 16,466 Scientific Journal Series of the Minnesota Agricultural Experiment Station in cooperation with Animal Science Research Division, ARS, USDA as a contribution to the Regional Project NC-111, Increased Efficiency of Sheep Production.
}

dairy sheep in the U.S.A. since research on this topic was initiated at the University of Minnesota (2). This research was initially focused on evaluation of the milk production performance of various breeds and crossbreds with the aim of examining methods to improve the milking ability of ewes nursing lambs. The number of lambs born per ewe has been substantially increased by some producers in recent years. This increased productivity has in most cases been the result of the introduction of the Finnsheep $(\mathrm{F})$ breed with its high rate of prolificacy. The increased lambing rate has also come about as a conse- 
quence of improvements in nutrition, management and flock health. However, the increased reproductive rate has not been accompanied by a concomitant increase in milk production to rear the greater number of lambs born per ewe. It is commonly recognized that limitations on milk production of the ewe is a major constraint on lamb growth. This restricts the opportunity to produce market weight lambs directly from ewes consuming a forage type diet. Lambs are often offered a concentrate supplement (creep) to augment their intake of milk from their dams. High producing dairy sheep breeds from Europe are not available in the U.S. The objective of this paper is to present some results of an experiment with milking sheep in Minnesota. The experiment provided an opportunity to make a direct comparison of the performance of the F, Romanov (R) and several U.S. breeds.

\section{Methods and materials}

An experiment was designed to measure milk production of several pure breeds and crossbreds. Ewes placed on the experiment were chosen at random from the breed groups. Ewes assigned to the trial were machine milked $2 \mathrm{X}$ daily following weaning of their lambs at 30 days of age. Ewes on the trial were milked for about 130 days post weaning (late Apr. to Sept.). Milk production was measured once a week in liters, for individual ewes. Total milk production for each week was calculated by using the weekly value. Milk samples were taken on a biweekly basis to determine milk composition.

The breeds evaluated in the trial were the F, Dorset (D), Lincoln (L), Rambouillet (Ra), Suffolk (S), Targhee (T) and R. The breeds were evaluated over a four year period from 1985 to 1988 except the R. A small flock of the $\mathrm{R}$ breed was assembled following importation of pregnant ewes from Canada in 1987. Data on the R were collected for two years, 1987 and 1988. The data on the $\mathrm{R}$ are thus limited relative to the other breeds. The $\mathrm{F}$ and $\mathrm{R}$ are breeds which are internationally recognized for their superior prolificacy $(3,5)$.

The F, D, L and R breeds had been mated in a diallel mating design in a prior experiment to study lamb growth. Purebred and crossbred ewes produced from this mating design were available for the milking trial.

The data in the trial were analyzed in two separate analyses. All purebred ewes, including purebred ewes produced in the diallel design, were analyzed by one analysis. The second analysis was made using only data from ewes produced by the diallel mating design. Conventional least-squares procedures were employed for the analyses (4).

\section{Results and discussion}

The form of the analyses of variance and mean squares for milk production traits for the purebred groups are shown in Table 1.

Table 1. Analysis of variance and mean squares for milk traits of seven breeds.

\begin{tabular}{|c|c|c|c|c|c|c|c|}
\hline \multirow[t]{2}{*}{ Source of variance } & \multirow[t]{2}{*}{ d.f. } & \multirow{2}{*}{$\begin{array}{l}\text { Milk yld } \\
130 \mathrm{~d} \text { (1) }\end{array}$} & \multirow{2}{*}{$\begin{array}{l}\text { Avg daily } \\
\text { yld }(\mathrm{ml})\end{array}$} & \multicolumn{4}{|c|}{ Milk composition $(\%)$} \\
\hline & & & & Fat & Protein & Lactose & $\begin{array}{l}\text { Total } \\
\text { solids }\end{array}$ \\
\hline Year & 3 & $2169.01^{* *}$ & $125172^{* *}$ & $7.43 * *$ & $2.60^{* * *}$ & $.76^{* *}$ & $5.36^{* *}$ \\
\hline Breed & 6 & $1909.90^{* *}$ & $114968^{* *}$ & $1.80^{* *}$ & $1.59 * *$ & .10 & $6.37^{* *}$ \\
\hline $\begin{array}{l}\text { Age } \\
\text { Covariate days }\end{array}$ & 3 & 233.84 & 14265 & .85 & .09 & $.28 * *$ & $4.34^{* *}$ \\
\hline on trial & 1 & $5531.93^{* *}$ & 63703 & .07 & .08 & .00 & .09 \\
\hline Error & 132 & 486.35 & 30502 & .48 & .16 & .05 & 1.10 \\
\hline
\end{tabular}

$* * \mathrm{P}<.01$ 
Variation among years was observed for all traits. Breed differences were significant for all traits except lactose percentage. Effect of age of ewe was limited but differed for lactose and total solids.

Least-squares means for the seven purebred groups and age of ewe are shown in Table 2. The $\mathrm{S}$ was the superior breed for total milk yield over the 130 day period, followed closely by the $\mathrm{Ra}$ and $\mathrm{T}$. The $\mathrm{D}$ followed next in rank in milk production. The $\mathrm{F}$ and $\mathrm{L}$ were similar to each other and lower than the other standard breeds. The $\mathrm{R}$ had the lowest performance (Table 2). Some caution should be exercised in reviewing the performance observed for the R. The sample size was limited. The flock was established in 1987 and data were available only from two years versus four years for other breeds.

The values for milk production found in this study are substantially lower than values reported for certain European and Middle Eastern breeds. Milk production values, per lactation for certain breeds, reported in System Solutions for Dairy Sheep (1) include: East Friesian 550 to $650 \mathrm{~kg}$, Lacaune 150 liters, Sarda 250 liters, Chios 170 to $270 \mathrm{~kg}$ and Awassi $200 \mathrm{~kg}$.

The $\mathrm{F}$ breed produced milk with the lowest percentage fat $(5.7 \%)$. The $\mathrm{R}(6.4 \%)$ was similar to the other breeds. The D had the largest percent of protein $(6.3 \%)$ followed closely by the $\mathrm{Ra}$ and $\mathrm{R}(6.1 \%)$. The $\mathrm{F}$ had the lowest percentage of total solids $(16.7 \%)$; a reflection also of its lower value for fat. The $\mathrm{R}$ was among the breeds with the highest amount of total solids (18.1\%) (Table 2).

The analyses of variance results of ewes produced from the diallel mating design are presented in Table 3. In this set of data no breed differences were observed (F, D, L and $\mathrm{Ra}$ ). However, a highly significant difference was observed in crossbreds, compared to purebreds, for total milk yield and average daily yield.

The least-squares means for performance of ewes from the diallel mating are shown in Table 4 for the purebreds, certain crossbreds and heterosis. Although no breed differences were observed in the analysis of these data, the pattern of performance is similar to that shown in Table 2 for all seven purebred groups. The $\mathrm{Ra}$ had the highest total milk yield and the $\mathrm{F}$ the lowest. In view of the lower performance of the $\mathrm{F}$ breed it is of special interest to note the performance of the F1 ewes in the diallel mating design. $\mathrm{F}$ crossbred ewes had the highest level of milk production and exceeded

Table 2. Least-squares means for milk traits for seven breeds and four age groups.'

\begin{tabular}{|c|c|c|c|c|c|c|c|}
\hline \multirow[t]{2}{*}{ Category } & \multirow{2}{*}{$\begin{array}{l}\text { Number of } \\
\text { records }\end{array}$} & \multirow{2}{*}{$\begin{array}{l}\text { Milk yld } \\
\text { 130d (1) }\end{array}$} & \multirow{2}{*}{$\begin{array}{l}\text { Avg daily } \\
\text { yld }(\mathrm{ml})\end{array}$} & \multicolumn{4}{|c|}{ Milk composition $(\%)$} \\
\hline & & & & Fat & Protein & Lactose & Total solids \\
\hline Overall mean & 146 & 68.8 & 550.1 & 6.2 & 5.9 & 4.8 & 16.7 \\
\hline \multicolumn{8}{|l|}{ Breed } \\
\hline Finn (F) & 23 & $64.0^{\mathrm{m}}$ & $509.1^{\mathrm{a}}$ & $5.7^{\mathrm{a}}$ & $5.5^{\mathrm{a}}$ & $4.8^{\mathrm{ac}}$ & $16.7^{\mathrm{a}}$ \\
\hline Dorset (D) & 22 & $69.2^{\mathrm{ab}}$ & $550.7^{\mathrm{ab}}$ & $6.5^{b}$ & $6.3^{\mathrm{c}}$ & $4.7^{\mathrm{bc}}$ & $18.1^{\text {bd }}$ \\
\hline Lincoln (L) & 24 & $63.7^{\mathrm{a}}$ & $507.1^{\mathrm{a}}$ & $6.2^{\mathrm{b}}$ & $5.9^{\text {bd }}$ & $4.8^{\mathrm{ab}}$ & $17.2^{\text {ace }}$ \\
\hline Rambouillet (Ra) & 20 & $75.3^{\mathrm{ab}}$ & $599.9^{\mathrm{ab}}$ & $6.6^{b}$ & $6.1^{\mathrm{de}}$ & $4.9^{9}$ & $18.2^{\mathrm{d}}$ \\
\hline Suffolk (S) & 24 & $80.5^{b}$ & $643.3^{\mathrm{b}}$ & $6.4^{b}$ & $5.9^{\text {bd }}$ & $4.8^{\mathrm{a}}$ & $17.9^{\mathrm{bd}}$ \\
\hline Targhee $(\mathrm{T})$ & 23 & $73.3^{\mathrm{ab}}$ & $584.3^{\mathrm{ab}}$ & $6.2^{\mathrm{b}}$ & $5.8^{\mathrm{b}}$ & $4.8^{\mathrm{ac}}$ & $17.5^{\mathrm{bc}}$ \\
\hline Romanov (R) & 10 & $39.1^{\mathrm{c}}$ & $326.5^{c}$ & $6.4^{b}$ & $6.1^{\text {bee }}$ & $4.8^{\mathrm{ab}}$ & $18.1^{\text {bde }}$ \\
\hline \multicolumn{8}{|l|}{ Age } \\
\hline $2 \mathrm{yr}$ & 51 & 65.3 & 525.2 & $6.1^{\mathrm{a}}$ & 6.0 & $4.9^{a}$ & $17.7^{a}$ \\
\hline $3 \mathrm{yr}$ & 49 & 66.1 & 528.9 & $6.4^{b}$ & 6.0 & $4.8^{a c}$ & $17.9^{a}$ \\
\hline $4 \mathrm{yr}$ & 25 & 63.2 & 504.8 & $6.2^{\mathrm{ab}}$ & 5.9 & $4.7^{\mathrm{b}}$ & $17.1^{\mathrm{b}}$ \\
\hline $5+y r$ & 21 & 71.1 & 567.3 & $6.4^{\mathrm{ab}}$ & 6.0 & $4.8^{\mathrm{bc}}$ & $18.0^{\mathrm{a}}$ \\
\hline
\end{tabular}

1 Means not having a common superscript differ significantly $(\mathrm{P}<.05)$ 
the better purebred breed in the diallel (Table 4). Generally the crossbred ewes performed well and this resulted in a positive heterotic effect $(15.4 \%)$ for milk yield. Similarly average daily yield showed a heterotic effect $(16.5 \%)$. Milk composition traits had low heterotic values except protein percent $(9.4 \%)$ (Table 4).

While $\mathrm{F}$ crossbred ewes were superior in milk yield and in average daily yield, they were the lowest in percent fat in the milk $(5.63 \%)$ (Table 4). The Ra crossbred ewes produced

Table 3. Analysis of variance and mean squares for four breed diallel mating for milk traits.

\begin{tabular}{|c|c|c|c|c|c|c|c|}
\hline \multirow[t]{2}{*}{ Source of variance } & \multirow[t]{2}{*}{ d.f. } & \multirow{2}{*}{$\begin{array}{l}\text { Milk yld } \\
130 \mathrm{~d}(1)\end{array}$} & \multirow{2}{*}{$\begin{array}{l}\text { Avg daily } \\
\text { yld }(\mathrm{ml})\end{array}$} & \multicolumn{4}{|c|}{ Milk composition $(\%)$} \\
\hline & & & & Fat & Protein & Lactose & $\begin{array}{l}\text { Total } \\
\text { solids }\end{array}$ \\
\hline Year & 3 & $1908.24^{*}$ & $119533^{*}$ & $8.63^{* *}$ & $2.61^{* *}$ & $1.09^{* *}$ & $4.57^{*}$ \\
\hline Purebreds & 3 & 871.89 & 53529 & $3.26^{* *}$ & $2.71^{* *}$ & $0.23^{*}$ & $11.22^{* *}$ \\
\hline Crossbreds & 1 & $6768.68^{* *}$ & $410872^{* *}$ & $2.60^{*}$ & 0.55 & 0.08 & 0.14 \\
\hline $\begin{array}{l}\text { General combining } \\
\text { ability }\end{array}$ & 3 & $3687.38^{* *}$ & $240749 * *$ & $4.38^{* *}$ & $1.07^{* *}$ & 0.15 & $7.77^{* *}$ \\
\hline $\begin{array}{l}\text { Specific combining } \\
\text { ability }\end{array}$ & 2 & $10195.11^{* *}$ & $649016^{* *}$ & 0.56 & 0.03 & 0.16 & 1.97 \\
\hline Maternal & 3 & $2800.30^{* * *}$ & $174287^{* *}$ & $1.57^{*}$ & 0.17 & $0.29^{* *}$ & 1.12 \\
\hline Reciprocal & 3 & $4342.84^{* *}$ & $278586^{* *}$ & 1.15 & 0.36 & $0.29^{* *}$ & 2.74 \\
\hline Age & 3 & 154.81 & 7688 & 0.91 & 0.00 & $0.24^{*}$ & 0.70 \\
\hline Covariate days on trial & 1 & $19201.99^{* *}$ & $381090^{* *}$ & 0.21 & 0.37 & $0.24^{*}$ & 0.07 \\
\hline Error & 231 & 656.23 & 42062 & 0.49 & 0.22 & 0.07 & 1.35 \\
\hline
\end{tabular}

$* \mathrm{P}<.05$

$* * \mathrm{P}<.01$

Table 4. Least-squares means for several milk traits, diallel mating (1985-88)'

\begin{tabular}{|c|c|c|c|c|c|c|c|}
\hline \multirow[t]{2}{*}{ Category } & \multirow{2}{*}{$\begin{array}{l}\text { Number of } \\
\text { records }\end{array}$} & \multirow{2}{*}{$\begin{array}{l}\text { Milk yld } \\
\text { 130d (l) }\end{array}$} & \multirow{2}{*}{$\begin{array}{l}\text { Avg daily } \\
\text { yld }(\mathrm{ml})\end{array}$} & \multicolumn{4}{|c|}{ Milk composition $(\%)$} \\
\hline & & & & Fat & Protein & Lactose & Total solids \\
\hline Overall mean & 254 & 72.68 & 580.0 & 6.13 & 5.89 & 4.81 & 17.53 \\
\hline \multicolumn{8}{|l|}{ Purebred } \\
\hline Finn & 23 & 66.21 & 529.8 & $5.59^{\mathrm{b}}$ & $5.45^{\mathrm{c}}$ & $4.79^{b}$ & $16.64^{b}$ \\
\hline Dorset & 22 & 73.98 & 590.1 & $6.41^{\mathrm{a}}$ & $6.30^{\mathrm{a}}$ & $4.70^{b}$ & $18.10^{\mathrm{a}}$ \\
\hline Lincoln & 24 & 69.15 & 551.7 & $6.08^{a}$ & $5.82^{b}$ & $4.82^{\mathrm{ab}}$ & $17.21^{\mathrm{b}}$ \\
\hline Rambouillet & 20 & 81.38 & 648.4 & $6.44^{a}$ & $6.00^{b}$ & $4.96^{a}$ & $18.17^{a}$ \\
\hline \multicolumn{8}{|l|}{ Crossbreds ${ }^{2}$} \\
\hline F crosses & 38 & $84.39^{a}$ & $670.02^{\mathrm{a}}$ & $5.63^{\mathrm{a}}$ & 5.73 & 4.90 & $17.06^{\mathrm{a}}$ \\
\hline D crosses & 41 & $67.11^{\mathrm{b}}$ & $532.66^{\mathrm{b}}$ & $5.98^{b}$ & 5.90 & 4.81 & $17.56^{\mathrm{ab}}$ \\
\hline L crosses & 43 & $74.32^{\mathrm{ab}}$ & $589.01^{\mathrm{ab}}$ & $6.22^{b}$ & 5.82 & 4.76 & $17.45^{a}$ \\
\hline Ra crosses & 43 & $79.95^{\mathrm{ab}}$ & $641.52^{a}$ & $6.25^{b}$ & 5.94 & 4.84 & $17.87^{b}$ \\
\hline \multicolumn{8}{|l|}{ Heterosis } \\
\hline Purebreds & 89 & $67.01^{\mathrm{a}}$ & $535.85^{a}$ & $6.02^{\mathrm{a}}$ & 5.43 & 4.84 & 17.50 \\
\hline Crossbreds & 165 & $78.35^{b}$ & $624.15^{b}$ & $6.24^{b}$ & 5.94 & 4.80 & 17.56 \\
\hline Heterosis $(\%)$ & & 15.4 & 16.5 & 3.2 & 9.4 & -.1 & .3 \\
\hline
\end{tabular}

1 Means not having a common superscript differ significantly $(\mathrm{P}<.05)$

2 Grouped by breed of sire 
milk with the greatest amount of total solids $(17.87 \%)$. F crossbred ewes were lowest, but not significantly different from the D or L crossbred ewes in percentage total solids (Table 4$)$.

The results here show differences in milk production to exist among breeds available in the U.S. The two recognized prolific breeds, the $\mathrm{F}$ and $\mathrm{R}$, were relatively low milk producers. It should be noted that milk yields were not adjusted for differences in ewe body weight.

While the purebred $\mathrm{F}$ ewes had a low milk yield, the F1 Finn crossbred ewes were superior among the crosses. This finding gives support to utilizing the $\mathrm{F}$ breed to enhance reproductive performance by crossbreeding in order to increase litter size. Our results suggest that milk production of the $\mathrm{F}$ crossbred ewes will also be enhanced.

\section{References}

Alfa-Laval. 1981. System Solutions for Dairy Sheep. Published by Alfa-Laval, S-14700 Tumba, Sweden, 141 pp.

Boylan, W.J. 1984. Milk production in the ewe. National Wool Grower, 74 (4): 6-8.

FАнмч, M.H. 1986. Preliminary results on fertility, prolificacy, lamb production and carcass traits of Romanov sheep in Canada. Proc 3rd. World Cong. Genet. Appl. Livest. Prod., Lincoln, Nebraska, IX:
$559-564$.

HARVEY, W.R. 1975. Least-squares analysis of data with unequal subclass numbers. USDA, ARS 11-4.

Maijala, K. and Österberg, S. 1977. Productivity of pure Finnsheep in Finland and abroad. Livest. Prod. Sci., 4: 355-377.

Usitc, 1981. Summary of trade and tariff information. Cheese, TSUS Items 177.0-117.88. USITC Publ. No 841 (Oct. 1981), Washington, D.C. 90436. 